\title{
Return to Gold-Based Monetary System: Analysis Based on Gold Price and Inflation
}

\author{
Salmy Edawati Yaacob ${ }^{1} \&$ Sanep Ahmad ${ }^{2}$ \\ ${ }^{1}$ Department of Syariah, Faculty of Islamic Studies, The National University of Malaysia, Bangi, Malaysia \\ ${ }^{2}$ School of Economic, Faculty of Economics and Management, The National University of Malaysia, Bangi, \\ Malaysia \\ Correspondence: Salmy Edawati Yaacob, Department of Syariah, Faculty of Islamic Studies, The National \\ University of Malaysia, 43600 UKM, Bangi, Selangor, Malaysia. E-mail: salmy1001@yahoo.com
}

Received: October 7, 2013 Accepted: February 26, $2014 \quad$ Online Published: March 31, 2014

doi:10.5539/ass.v10n7p18 URL: http://dx.doi.org/10.5539/ass.v10n7p18

\begin{abstract}
Researchers and economists clarify that the problem of inflation and the currency instability occurs today is due to the implementation of monetary system which is not based on valuable commodity or gold as the gold standard of the previous system. As a sequence to this, there has been a proposal to create a Bretton Woods II system by the World Bank President, Robert Zoelick, recently in 2010. The question is whether the return to gold currency is justifiable in order to ensure world economic stability. Therefore, this study aims to analyze the historical data of the inflation rate and world gold price in order to identify a more stable financial system. The study will provide evidence that the gold standard era is the most stable era thus justifies the return to gold currency. This study uses time series data for a key economic indicator i.e. inflation rate starting from year 1880 to 2008 , divided into three phases of gold standard system; i.e. the full gold standard system (1880-1914) and the gold exchange standard system (1925-1931); the Bretton Woods system (1946-1972) and the fiat currency system (1973-2008), using regression model and CUSUM test. The results show that the rate of inflation and the value of world gold are much lower and more stable during the gold standard phases than the fiat money. This indicates that the move to return to gold currency is more apt in the bid to ensure global economic stability. However, more efforts are needed to resolve the implementation mechanism.
\end{abstract}

Keywords: gold currency, gold dinar, world economic crisis, gold standard phase, gold standard phase, floating fiat currency phase

\section{Introduction}

According to Hawtrey (1947), Marcuzzo \& Rosseli (1986), Meissner (2005) and Knafo (2006), the gold standard system is defined as the setting of currency value based on the weight of gold, and the free exchange and trade in the form of gold. The classical gold standard era began in 1880 until 1914. For Wanniski (1995), the gold standard system is defined as a government guarantee to the borrowers. If they borrow an ounce of gold today, it will be repaid with an ounce of gold in 10 years or 30 years later. This is a 'golden handshake' between the government and the public. The system was first introduced in England under Lord Liverpool Act in 1816 (Marcuzzo \& Rosseli, 1986) during the reign of Sir Isaac Newton. However, according to Duckenfield (2004), in England the currency was already unofficially tied to gold in the year of 1717, after the decline in the value of guinea silver currency issued by Sir Isaac Newton. Ruggiero (2002) also points out that the United States has made gold as an official standard starting in 1819 and fully implemented this system in 1834 and then in 1900 . At the time the Congress passed the Gold Standard Act, many countries only began to adopt this system within the period of 25 years between 1880 until 1914 (Cecco, 1974; Pence \& Hamzaid, 1990).

In general, the world monetary system was first initiated with a currency system based on valuable metal (bimetallic system in the early 7th century) after having undergone several changes in line with the needs and development at that time. The bimetallic system is a system based on metal currency with gold, silver, copper or bronze (Yaacob et al., 2012). Furthermore, the world adopted the goldsmiths system (1640-1800) following the growth in business dealings between man and the increase of coins in circulation. Thereafter, the monetary system has switched to the classical gold standard system (1821-1914) when several countries agreed to adopt a fixed exchange system based on the value of gold. However, after the World War I, the world has witnessed an adoption 
of a floating papers exchange system between the years of 1915-1925 and the return of gold standard after that, from 1925 until 1931. However, after the World War II and the Great Depression, once again floating currency system made its come back between the years 1931 until 1944. Consequently, beginning 1944 to 1971 i.e. in the span of 27 years, there has been a fixed exchange system based on the value of gold known as the Bretton Woods System. The Bretton Woods system however ended in 1971 and was replaced with a floating currency system, also known today as fiat money (Yaacob, 2009).

The problem of inflation and instability in currency values has started in 1933 during the Great Depression, followed by the Mexico Peso crisis in 1995, the currency depreciation crisis of the Asian countries (1997/98), the Russian Rouble crisis in 1998 and the recent global economic crisis in 2008 (Yaacob et al., 2011). These crises happen because of the instability of the value of fiat currency used in world economic system today. The world currency today is a floating fiat currency which is pegged to the U.S. dollar whose value will change with changes in the money market, i.e. the total demand and supply of dollars. This makes the currency values unstable. Beginning 1980s, inflation has become a serious problem to the western countries and often become the focus of policy debate. Therefore, a proposal is put forward for the world to free itself from reliance on fiat currency and to return to gold standard due to its stability in its value and its ability to contain inflation (Yaacob, 2011).

However, the justification for this effort should be investigated further to determine whether the world was in a general equilibrium during the gold standard era or was it otherwise? In addition to that, different methods of analysis should be used to obtain a more convincing conclusion. Thus, this study aims to analyze whether the era of gold standard is a stable era so as to justify the efforts to return to gold standard currency system.

\section{Literature Review}

Several previous studies disclose that the inflation rate and gold price vary according to monetary policy, whether a gold-based system (gold standard) or a floating system (fiat money system). High and varying inflation rate are the main economic problems faced by all systems of economic. Thus, there are many economists who have made comparison studies between inflation rate and monetary system, among them are Bordo et.al (2007), Bordo (1999), Jastram (1997), Craig (1995), (Bordo, 1993), Kehoe (1992) and al-Maqrizi (1957).

Through history starting with the bimetallic system up to fiat system has shown records of inflation during these periods. A significant difference between these periods of time is the main cause of inflation. For example, the inflation factor of the bimetallic system and the fixed gold standard was the result of war and the discovery of gold resources on a large scale. These factors may be very difficult or impossible to occur at present. However, unlike the inflation factors in the floating systems, these factors will exist throughout time so long as the currency is afloat with no back up, as being practiced today. This was stressed by Mundell (1995) in his study related to 'The International Monetary System: The Missing Factor'. Mundell (1995) believe with his empirical evidence which has shown how inflation has almost never occurred under the era of gold standard and the Bretton Woods systems, which differ with the regime of currency not backed by gold (floating system). This was because the commitment of exchange method mechanism during the gold-standard was fixed and stable. This system is different from the current monetary system (floating system) because there is a non-consistency condition of the government optimal policy for there is no leading single mechanism to guide the government towards policy stability when it comes to addressing the problem of inflation.

According to Eichengreen (1991), the stability of the gold standard before the war can be attributed to two factors that is trustworthiness and collaboration. Trustworthiness and collaboration is central to the smooth operation of the gold standard before the war. After World War I, both the scope of this role has declined. Instability of gold standard during the period of war is a testament to the loss of trust and collaboration among the countries practicing the gold standard system. There are several studies showing that during the period of the classical gold standard from 1717 until 1914 the price of gold is stable and has almost no inflation.

Meanwhile, Kehoe (1992) has conducted research related to changes in output, prices and currency for 10 countries (Australia, Canada, Denmark, Germany, Italy, Japan, Norway, Sweden, United Kingdom and United States) for the three periods i.e. before World War I, after World War II and between World War I and World War II. The study found that in all 10 countries, there has been a great change in real output during the period between World War I and World War II than after World War II. Many other countries also have significant and prolonged inflation rate after World War II.

The study by Al-Maqrizi (1957) has shown that the first inflation that occurred in the world economy is during the time of the Mamluk government between the years 1382-1517. At that time, al Maqrizi (1957) identified that, inflation has occurred due to the mass printing of copper currency (fulus) as a fraction of money and without 
specific standards. After that, inflation has continued to exist in the world economic system, in certain periods and phases up to this day. This is indirectly supported by a study done by Friedman (1975) which states that the early inflation was due to the instability problem of the bimetallic system which was due to the alternate use between gold and silver currency. The statement was further reinforced by the view of Lee \& Pasell (1979) and Mansor (1990) which state that the increase in prices at that time was due to the increase of inflow of currency either gold or silver that was brought into Europe and the United States. Friedman (1975) explains that an early stage of inflation did occur when a massive gold was discovered in Australia and California in 1850. The situation has led to a world inflation causing a rapid increase in the quantity of money. In addition, according to Ruffin \& Gregory (1983), the same situation also occurred between the years 1833 to 1836 in which currency plus bank notes has increased by 64 percent due to the increase in the money stock in the form of silver inflows from Mexico. Although inflation has occurred in the $1830 \mathrm{~s}$, at the same time there is an increase of money in circulation

Study by Jastram (1997) has shown a new period of economic instability which has begun with the termination of the bimetallic system in 1873. However, deflation did occur during the period of 1873 due to the after impacts of the Nepoleon War (1803-1815). This situation ended when gold was discovered which has escalated the demand for gold. Following this, production and minting of gold has marked the end of inflation until 1920. The problem of inflation also often occured in countries adopting a currency standard (specie standard) during the period of war such as the Nepoleon War (1803-1815), U.S. Civil War (1861-1865), World War I (1914-1918) and World War II (1939-1945). As evidence, during the France revolution, countries such as France, Holland, Britain and several other countries, all have adopted the currency standards following the fall of gold value (due to inflation). Whilst Britain, Austria-Hungary, Russia and a few other countries return back to the currency standards (due to deflation) after World War I (Bordo, 1999). Most of the countries who returned to gold standard are those who have been buying gold and selling silver, thus creating inflation for countries using silver and deflation for countries using gold.

In summary, history has proved that war and the discovery of gold on a large scale are two conditions that lead to inflation and deflation in the bimetallic and classical gold standard. However, according to Bordo (1992), the gold standard system was showing the in and outflow of gold of the big countries which were kept under scrutiny and stable balance of payments position. The policy of the gold standard system in maintaining balance is to restrict economic activity in order to restore the value of gold when value of gold declines. The empirical evidence also clearly shows no evidence of inflation under the gold standard and the Bretton Woods systems compared to system not backed with gold. In the early implementation of the Bretton Wood system, there was a relatively high inflation rate for the United States (Bordo, 1992). However, the occurrence of inflation is not considered unusual. According to Mansor (1990), the same inflation also hit several other countries after World War I. Inflation in the years 1946-1948 is considered as moderate than compared to inflation in Germany in 1922 Whereas in 1950 until 1960, the average inflation rate in the United States was 1.99 per cent per annum. Similarly, inflation in other industrialized countries has been relatively low and the increase in retail price is only around 2 to 4 percent a year.

Whereas in the 1970s, history of world inflation has recorded a first ever inflation that is rare and unusual. This situation occurs in 1973 and 1974, but at the same time there is a high price increase in 1979 even though inflation has not yet fully recovered. Inflation rate in the 1970s has hit high and this has continued for several years. Various efforts were made to curb inflation, but the rate remained high. Inflation has become an international phenomenon when almost all countries that adopt free trade also experience it although at varying rates. According to Ruggiero (2002), this occurs because, psychologically, the dollar is not pegged to gold, which leads to rapid inflation reaching almost $14 \%$ in 1980 . Therefore, he argues that the continuing inflation that occurred in the 1970s has to do with the dissolution of gold bonding in the international financial system in 1971. This view is shared by Sjaastad (1996) in which floating exchange rates between major currencies led to instability of the world gold market after the dissolution of the Bretton Woods system. This is because the effect of appreciation or depreciation in the value of European currencies against the gold price in the form of other currencies. This situation also shows that there is a close relationship of inflation rate with rate of growth of money supply. Money supply growth rate is higher in countries with high inflation. Meanwhile, in countries that do not experience inflation, the rate of growth of money supply is more under controlled (Ruggiero, 2002). Therefore, it can be said that the gold standard has long been associated with long-term price stability (Gallarotti, 2005).

After the incident of inflation in the 1970s, there were several occurrence of financial crises after the world economy adopted the floating currency system. In July 1997, there was the currency depreciation crisis of the Asian countries. The countries severely affected were Indonesia, Korea, Malaysia and the Philippines. 
Meanwhile, the global economic crisis or the 2008 United States financial crisis is considered as the crisis of the 21 st century. This crisis was referring to the collapse of the economy, trade, and housing sub-prime mortgages which has started in 2007 and has continued until 2008. This situation is considered as similar to the Asean Financial Crisis of 1998. Even few of the economists think that this crisis is the second Great Depression of the 1930.Thus, based on discussions in previous studies which relate to the problem of inflation and global economic crisis, a question is raised of whether the rationale to return to the use of gold coins or gold standard is rational in order to guarantee global economic stability and to curb inflation?

\section{Method}

Regression analysis and CUSUM tests are used to evaluate the event of a significant structural change for different currency phase during the era of the gold standard, Bretton Woods and the floating system. Two methods are chosen for their simplicity and reliability in assessing structural changes and parameters instability. In regression analysis, dummy variables ( $D 1$ and $D 2)$ are used to represent two different phases. In designing the model, the variables consider the time trend $t$ and dummy variables, taking the era of floating fiat currencies as a group basis, the model used is as follows (Gujarati, 2003):

$$
Y=\alpha+\beta_{1} * t+\sigma_{1} * D 1+\sigma_{2} * D 2
$$

Where:

$$
\begin{aligned}
& \mathrm{Y}=\text { Inflation rate/Gold price } \\
& \mathrm{t}=\text { Time in years } \\
& \mathbf{D 1}=\left\{\begin{array}{c}
1 \text { Gold standard system } \\
0 \text { Others }
\end{array}\right. \\
& \mathbf{D 2}=\left\{\begin{array}{c}
1 \text { Bretton Woods system } \\
0 \text { Others }
\end{array}\right.
\end{aligned}
$$

Furthermore, the analysis also uses CUSUM test to test for model stability. The analysis is based on the sum of cumulative residuals. The model used in CUSUM test is:

$$
e_{t}=y_{t}-x_{t}^{\prime} b_{t-1}
$$

The estimated variance for this residual is:

$$
\sigma_{f t}^{2}=\sigma^{2}\left\{1+x_{t}^{\prime}\left(X_{t-1}^{\prime} X_{t-1}\right)^{-1} x_{t}\right\}
$$

The $\mathrm{r}^{\text {th }}$ scaled residual is:

$$
w_{r}=\frac{e_{r}}{\sqrt{1}+x_{r}^{\prime}\left(X_{r-1}^{\prime} X_{r-1}\right)^{-1} x_{r}}
$$

CUSUM test is based on the sum of accumulated residuals:

Where,

$$
w_{t}=\sum_{r=K+1}^{r=1} \frac{w^{r}}{\sigma^{2}}
$$

$$
\sigma^{2}=\frac{1}{T-K-1} \sum_{r=K+1}^{T}\left(w_{r}-\bar{w}\right)^{2}
$$

and,

$$
w=\frac{1}{T-K} \sum_{r=K+1}^{r=T} W_{r}
$$

Based on the formula above, $w$ is recursive residuals and $\sigma$ is the standard error. The subscript $K$ gives the number of parameters estimated, $t$ is number of observations and $T$ is the number of samples.

\subsection{Empirical Results}

The analysis uses time series data for inflation rate and the world gold price beginning 1880 until 2008 obtained online. The time period of 129 years is long enough to allow subdivision of three currency eras, i.e. the gold standard system (1880-1931), Bretton Woods system (1946-1972) and fiat currency system (1973-2008). Results of data stationarity tests is shown in Table 1 and Table 2.

\subsection{Data Stationary Test}

The stationarity test results shown in Table 1 and Table 2 show that the time series data for inflation rate and gold 
price are stationary. The ADF statistical values for both parameters in the first difference i.e. D(INFLASI) and $\mathrm{D}$ (HARGA) respectively are both significant at 1 percent level. The stationarity of these time series data will prevent from false regression.

Table 1. Inflation stationarity test

Null Hypothesis: D(INFLASI) has a unit root

Exogenous: Constant

Lag Length: 1 (Automatic - based on AIC, maxlag=12)

\begin{tabular}{|c|c|c|c|}
\hline & & t-Statistic & Prob.* \\
\hline \multicolumn{2}{|c|}{ Augmented Dickey-Fuller test statistic } & -13.00165 & 0.0000 \\
\hline \multirow[t]{3}{*}{ Test critical values: } & $1 \%$ level & -3.495677 & \\
\hline & $5 \%$ level & -2.890037 & \\
\hline & $10 \%$ level & -2.582041 & \\
\hline
\end{tabular}

*MacKinnon (1996) one-sided p-values.

Augmented Dickey-Fuller Test Equation

Dependent Variable: D(INFLASI,2)

Method: Least Squares

Date: 09/15/10 Time: 15:39

Sample (adjusted): 4105

Included observations: 102 after adjustments

\begin{tabular}{|c|c|c|c|c|}
\hline Variable & Coefficient & Std. Error & t-Statistic & Prob. \\
\hline D(INFLASI(-1)) & -1.582848 & 0.121742 & -13.00165 & 0.0000 \\
\hline D(INFLASI(-1),2) & 0.534192 & 0.084630 & 6.312080 & 0.0000 \\
\hline $\mathrm{C}$ & 0.042934 & 0.255756 & 0.167873 & 0.8670 \\
\hline R-squared & 0.654673 & \multicolumn{2}{|c|}{ Mean dependent var } & 0.009706 \\
\hline Adjusted R-squared & 0.647697 & \multicolumn{2}{|c|}{ S.D. dependent var } & 4.351584 \\
\hline S.E. of regression & 2.582888 & \multicolumn{2}{|c|}{ Akaike info criterion } & 4.764664 \\
\hline Sum squared resid & 660.4596 & \multicolumn{2}{|c|}{ Schwarz criterion } & 4.841869 \\
\hline Log likelihood & -239.9979 & \multicolumn{2}{|c|}{ Hannan-Quinn criter } & 4.795927 \\
\hline F-statistic & 93.84253 & \multicolumn{2}{|c|}{ Durbin-Watson stat } & 2.135762 \\
\hline Prob (F-statistic) & 0.000000 & & & \\
\hline
\end{tabular}

Note: INFLASI $=$ parameter for inflation. 
Table 2. Gold price stationarity test

Null Hypothesis: D(HARGA) has a unit root

Exogenous: Constant

Lag Length: 0 (Automatic - based on AIC, maxlag=12)

\begin{tabular}{lccc} 
& & t-Statistic & Prob.* $^{*}$ \\
\hline Augmented Dickey-Fuller test statistic & -7.530395 & 0.0000 \\
Test critical values: & $1 \%$ level & -3.495021 & \\
& $5 \%$ level & -2.889753 & \\
$10 \%$ level & -2.581890 & \\
\hline
\end{tabular}

*MacKinnon (1996) one-sided p-values.

Augmented Dickey-Fuller Test Equation

Dependent Variable: D(HARGA,2)

Method: Least Squares

Date: 09/08/10 Time: 12:31

Sample (adjusted): 3105

Included observations: 103 after adjustments

\begin{tabular}{|c|c|c|c|c|}
\hline Variable & Coefficient & Std. Error & t-Statistic & Prob. \\
\hline D(HARGA(-1)) & -0.781552 & 0.103786 & -7.530395 & 0.0000 \\
\hline $\mathrm{C}$ & 6.834047 & 4.741394 & 1.441358 & 0.1526 \\
\hline R-squared & 0.359571 & \multicolumn{2}{|c|}{ Mean dependent var } & 1.714272 \\
\hline Adjusted R-squared & 0.353230 & \multicolumn{2}{|c|}{ S.D. dependent var } & 59.21591 \\
\hline S.E. of regression & 47.62261 & \multicolumn{2}{|c|}{ Akaike info criterion } & 10.58372 \\
\hline Sum squared resid & 229059.2 & \multicolumn{2}{|c|}{ Schwarz criterion } & 10.63488 \\
\hline Log likelihood & -543.0615 & \multicolumn{2}{|c|}{ Hannan-Quinn criter. } & 10.60444 \\
\hline F-statistic & 56.70685 & \multirow{2}{*}{\multicolumn{2}{|c|}{ Durbin-Watson stat }} & 1.876875 \\
\hline Prob (F-statistic) & 0.000000 & & & \\
\hline
\end{tabular}

Note: HARGA = parameter for gold price.

\section{Results}

\subsection{Regression Analysis}

The results of estimated regression model for inflation rate and gold price are shown in Table 3 as the following:

Table 3. Results of estimated model

\begin{tabular}{lll}
\hline Coefficients & Inflation rate model & Gold price model \\
\hline constant & $11.110^{* * *}$ & $119.748^{*}$ \\
$\mathrm{~T}$ & $-0.073^{* * *}$ & $2.800^{* * *}$ \\
$\mathrm{D}_{1}$ & $-9.774^{* * *}$ & $-159.369^{* * *}$ \\
$\mathrm{D}_{2}$ & $-3.779^{* * *}$ & $-240.220^{* * *}$ \\
\hline
\end{tabular}

Notes: Refer to Appendix 1 (a) and (b)

*** Significant at $1 \%$ level of significance

* Significant at $10 \%$ level of significance

Based on Table 3 we can see that the coefficient value for inflation rate model is significant for all parameters. Coefficients for $D 1$ and $D 2$ are -9.774 and -3.779 respectively and both are significant at 1 percent significance level $(p$-value $<0.01)$. This means that inflation rate during the gold standard era and Bretton Woods system are much lower compared to inflation rate during the fiat currency system. The results show that inflation rate and 
gold price are both significantly high compared to the currency system in the era before it. Therefore, inflation rate and gold price can be assumed as stable during the gold standard era and there exists a structural difference during the fiat floating currency era.

\subsection{CUSUM Test}

The result of CUSUM test for inflation rate and gold price is shown in Figure 1 and Figure 2.

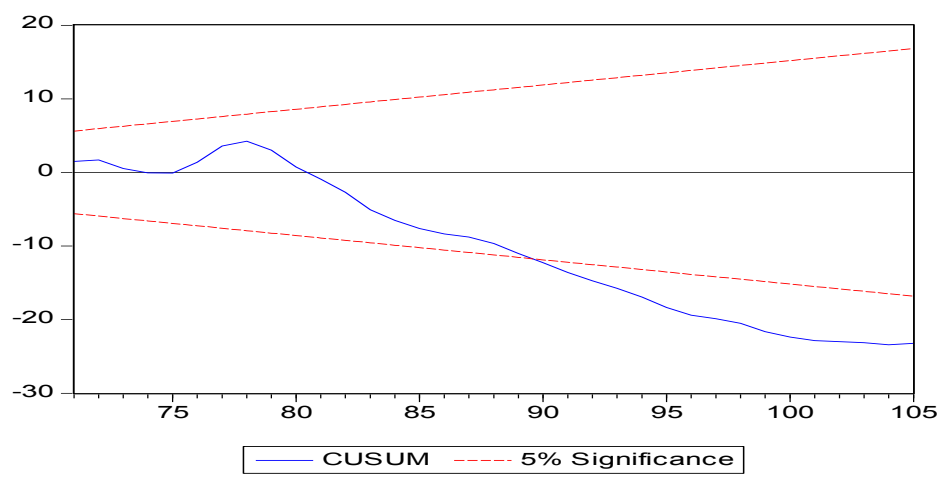

Figure 1. The result of CUSUM test on inflation rate

From Figure 1 we can observe result of CUSUM test for the parameter inflation which has indicated that it has exceeded the boundary constraint in the parameter interval of 90 , indicating the existence of economic instability which began in 1993 that is during the floating currency system. This situation explains that the inflation rate will experience a shock that causes a sharp increase in the inflation rate and wanders away from the bands during the floating fiat currencies. Results of regression estimation and CUSUM tests give the impression that the world economic situation with inflation rate as a proxy during the gold standard currency era is much lower and more stable than the era of floating fiat currency.

Figure 2 shows that the CUSUM test results for the gold price parameter has exceeded the parameter limits and wanders outside the boundary of the $80^{\text {th }}$ interval, indicating an existence of gold price instability and volatility which begins in 1983 that is during the start of floating fiat currency system until 1995. The gold price once again becomes stable between 1995 to 2003 but rose sharply again afterwards. This situation explains the relatively stable gold price in the era of the gold standard and Bretton Woods, but less stable in the era of floating fiat currencies. This is because at that time gold has been attributed to the value of fiat currency. This means the existence of gold price instability/volatility during the floating currency system. This gives the impression that the value of fiat currencies will continue to decline and the purchasing power would also decline if the value were attributed to the price of gold. This situation concludes that the currency value in the era of floating fiat currency is less stable than the currency value in the era of gold standard.

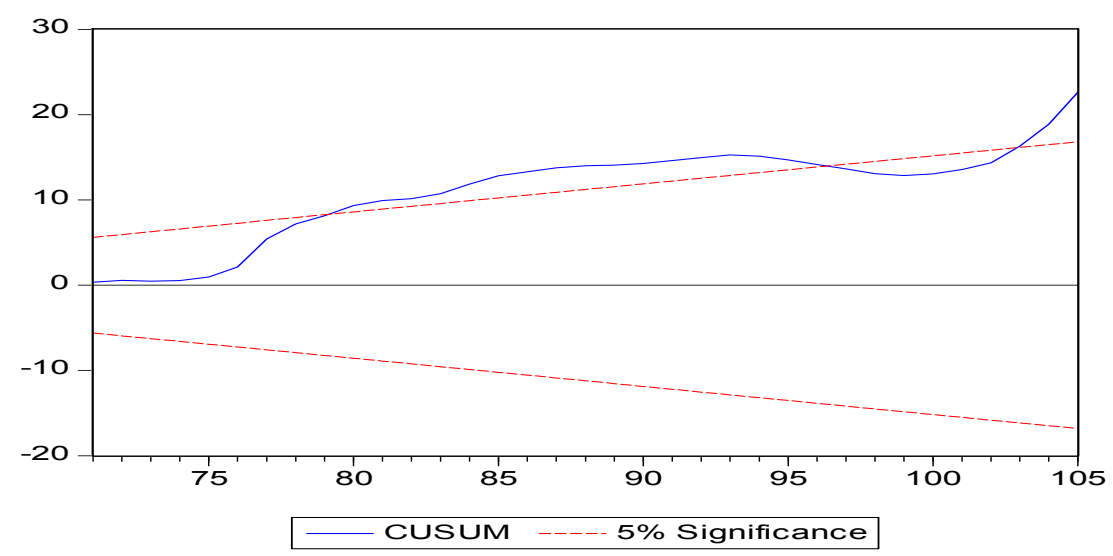

Figure 2. The result of CUSUM test on gold price 
Based on the results of the time regression and CUSUM test for inflation and gold price data has shown that inflation during the era of gold standard is more stable and much lower than the floating currency system. While the gold price during the gold standard era has shown a stability that is consistent than during the era of floating currency system. As such, the proposal for the world to return to the use of gold currency however is an option for mechanism that has its rationale for the good of world economic stability. Inflation rates and gold prices are expected to be much lower and more stable, which would be able to guarantee the stability of world economy.

\section{Discussion}

This study has examined the relationship of two economic indicators which can be associated with economic stability i.e. inflation rate and the price of gold. Based on results on the analysis of time regression and CUSUM test on inflation and gold price data has shown that inflation during the gold standard is much lower than during the floating currency system. While gold price during the gold standard era has shown a consistent stability than during the era of floating currency system. Thus, these findings support previous findings carried out by Bordo (2007; 1993; 1992), Lassonde (2005), Jastram 1997 and Craig (1995).

Previously, Bordo et.al (2007) has proven that the inflation rate during the period of gold standard is much lower than during the fiat currency system. He has made comparison on the average rate of inflation between two financial systems of the year for the period of 1880-1913 for gold standard, and 1968-2001 for fiat systems. Bordo et.al (2007) found that the average inflation rate during the gold standard system was much more lower at 0.9 compared to a floating currency system which is 5.3. Range of current inflation during the gold standard era was low between -0.6 and 3.0, while during the current floating currency, range of inflation is high between 3.8 and 8.2. This indicates that prices during the gold standard system are more stable than during floating currency system. The gold standard era that began in 1880 up to 1914 was the era of low inflation, stable exchange and rapid economic growth compared to the time between World War I and World War II (Bordo 1993). Craig's (1995) analysis also discovered the same findings where gold price and inflation rate was lower for the period of 1873-1913 compared to 1850-1913. The inflation rate was lower during the post-1873 due to the slow growth of gold supply that was slower than the economic growth of the countries. The annual average inflation rate also shows that the lowest rate occurred during the era of gold standard.

Based on the findings of these studies prove that the inflation rate is lower during the gold standard system, although different methods of analysis are used. The factors that lead to low inflation rate may differ, however, the overall average of findings has agreed on a consensus that the rate of inflation is much lower during the gold standard system than during the fiat currency system. Meanwhile, the results of our findings on gold prices stability during the gold standard era also support previous studies by Lassonde (2005), Bordo (1992) and Jastram 1997. Lassonde (2005) has shown that gold prices remained stable during the classical gold standard system for almost 200 years from 1717 until 1914. However, the period between the years 1800-1817 that is during the Nepoleon war is an exception when it has triggered inflation due to the difficulty in controlling gold price resolution. Meanwhile, starting in 1870 until 1914, gold as a whole became the standard currency. At that time, London's financial system dominated this standard and thus had demonstrated stability and strength of the British government. The basis of gold stability during that time was an abundance supply of gold and the discovery of gold extraction methods in the industry.

These findings are in line with the findings by Bordo (1992) which has shown that short-term price of gold act as a stabilizer for expected price because the gold price over the period 1821 to 1914 was relatively stable and almost has no inflation. Bordo (1992) also believes that should the countries have adopted the gold standard system since the 18th century until now, events throughout the system are almost non-existence of inflation than during the era of World War II when inflation is significant and positive. In addition, there are few studies of the Lassonde (2005) and Bordo (1992) who has shown historically that gold prices are always stable and will not be overly affected even during the period before the war. This was proved in 1901 when there was only a slight increase in the price of gold from USD $\$ 20.65$ to USD \$20.71. This shows that the great wars did not cause extreme affects to the price of gold. Gold prices also remained stable during the period of hyper inflation around the year 1918 until the year 1926 although the price of gold per ounce has experienced a slight increase. The average gold price in the nine years of hyper inflation is USD $\$ 20.74$ for an ounce. This situation explains that gold price remains stable even in hyper inflation situation.

While the findings of the study by Jastram (1997) also agree with the stability of gold price during the adoption of the gold standard system. Jastram (1997) conducted a proofing study on the long term trend stability of gold involving cycles of inflation and deflation over the period of 400 years and the data obtained cover the four largest countries i.e. the United States, United Kingdom, France and Germany. From the data he found that 
inflation has occurred since the year 1780 until 1815; deflation occurred until 1850; inflation until 1873; deflation until 1896; inflation until 1920, and deflation until 1935. Despite the frequent interruption of the economic cycles, the long term price of gold has always been stable because the rise in price during the expansion phase is always offset by the decrease in price during the contraction phase. His findings demonstrate that during the Great Depression that is between 1929 until 1933, gold prices remained stable and were hardly affected by the economic phenomena of the time. Gold prices recorded in 1929 was USD20.63 and a slight increase in 1933 of USD \$20.69. After the Great Depression, gold price continued to rise to USD \$30 per ounce, and continued to increase to USD\$35 per ounce after the end of the classical gold standard.

Jastram (1997) has shown that during the period of the Bretton Woods system, starting in 1944 until 1971, gold prices are at a relatively stable position of between USD $\$ 31.69$ up to USD $\$ 41.09$. In 1981, gold prices started to shrink again in contrast with the previous year when the global economy recovers from the global economic crisis. As a result, gold prices have declined by 32 percent and the highest recorded decline in the past 30 years. After that, gold prices recorded an average decline of 11 percent a year between the years 1980 to 1985. This occurs due to a decline in the U.S. inflation rate from 13.3 percent to 3.8 percent. Since 1980 until now, the price of gold has seen a frequent decline and increase in the short term. However, when trend is viewed in the long term, the price of gold is escalating every year. This is because gold is traded like other commodities that rely solely on market forces and market factors. According to Anikin (1983), the stability of gold is associated with the existence of anti-inflationary nature. This is because the purchasing power of gold is spontaneous and natural, and thus makes it easier for it to be stable in the long run, in contrast to the purchasing power of paper money which depends on how much paper money is printed and issued by a country. In theory, the gold standard system is more prone to stability than paper currencies.

In formulation, the findings of this study which is directed to the stability of gold prices during the gold standard system is consistent with the findings of previous studies. This situation proves that the gold standard is the only monetary system that has been through a phase of consistent currency stability in the long term compared with the floating system. Thus, it is not surprising when there are proposals from economists and academics asking to reconsider the return to implementation of the gold standard system, following the failure of western countries to control inflation as seen in recent decades.

\section{Conclusion}

Through historical experience of the world monetary system, it is found that the practice of gold-backed currency system starting with the gold standard system, gold exchange standard, until the Bretton Wood system shows that the movement of inflation and the value of currency (gold price) are more stable compared to the floating currency system, which began in 1971 until now. Therefore, this study has shown that inflation at the time of the gold standard is more stable and lower than the floating currency system. Meanwhile, gold prices during the gold standard era also has shown consistent stability compared to the era of fiat currencies. Therefore, the proposal to return to gold standard is a reasonable and justifiable step in order to ensure economic stability. Gold or real money has intrinsic value that is more secured without much influenced by the market environment of supply and demand. Thus, the proposal to return to gold system is expected to restore stability and harmonization of the financial system we had once enjoyed and indirectly will curb inflation. This situation is different from fiat money that can easily be printed and distributed without having a back-up mechanism to avoid speculation that could lead to crisis of currency depreciation like what has happened in Asia in mid-1997. Graham \& Whittlesey (1939) support the agenda to restore the use of gold as currency because in this way will bring a solution to the currency disequilibrium. These findings thus support the call by World Bank President Robert Zoellick to create a system of Bretton Woods II and suggestion from Tun Dr Mahathir Muhammad, former Prime Minister Malaysia to use gold dinar as an alternative currency in Malaysia (Yaacob, 2012; Yaacob $\&$ Ahmad, 2012). However, further studies are needed to come up with the best mechanism to use gold as a currency in today's modern world.

\section{References}

al-Maqrizi, T. al-D. A. (1957). al-Ighathah al-Ummah bi Kashfi al-Ghummah. Kaherah: Matba' ah Li al-Jannah.

Anikin, A. (1983). Gold--The Yellow Devil. Edisi ke-2. New York: International Publishers.

Bordo, M. D. (1992, March 22). The gold standard and other monetary regimes. (Research Summaries). NBER Reporter (Research Summaries).

Bordo, M. D. (1993, March). The gold standard, Bretton Woods and other monetary regimes: A historical appraisal. Federal Reserve Bank of St. Louis Review. 
Bordo, M. D. (1999). The Gold Standard and Related Regimes: Collected Essays. London: Cambridge University Press. http://dx.doi.org/10.1017/CBO9780511559624

Bordo, M. D., Choudhri Ehsan, U., \& Schwartz Anna, J. (1999, May). Was Stable Money Feasible during the Great Contraction? An Examination of the Gold Standard Constraint. NBER Working Paper, (7125).

Bordo, M. D., Dittmar, R. D., \& Gavin, W. T. (2007). Gold, Fiat Money, and Price Stability. The B.E. Journal of Macroeconomics, 7(1). Retrieved from http://www.bepress.com/bejm/vol7/iss1/art26

Cecco, M. D. (1974). Money and Empire: The International Gold Standard, 1890-1914. London: Basil Blackwell.

Craig et al. (1995). Inflation and money growth under the international gold standard, 1850-1913. Journal of Macroeconomics, 17(2), 207-226. http://dx.doi.org/10.1016/0164-0704(95)80097-2

Duckenfield, M. (2004). The Monetary History of Gold: A Documentary History, 1660-1999. London: Pickering \& Chatto.

Eichengreen, B. J. (1991, March 22). The gold standard and the Great Depression (the economic depression of the 1930s). NBER Reporter.

Friedman, M. (1975). Milton Friedman in Australia, 1975. Sydney: Constable and Bain.

Gallarotti, G. M. (2005). Hegemos of a lesser God: The Bank of France and monetary leadership under the classical gold standard. Review of International Political Economy, 12(4), 624-646. http://dx.doi.org/10.1080/09692290500240339

Graham, F. D., \& Whittlesey, C. R. (1939). Golden Avalanche. Princeton, NJ: Princeton University Press.

Gujarati, D. N. (2003). Basic Econometrics. New York, Mc Graw Hill.

Hawtrey, R. (1947). The Gold Standard in Theory and Practice. London: Longmans, Green and Co. Ltd.

Jastram, R. W. (1997). The Golden Constant: The English and American Experience 1560-1976. Barkeley: University of California.

Jusoh, M. (1990). Inflation. Kuala Lumpur: Dewan Bahasa dan Pustaka.

Jusoh, M., \& Yahya, H. (1990). International Financial Economic. Kuala Lumpur: Dewan Bahasa dan Pustaka.

Kehoe, D. K. B. P. J. (1992). International evidence on the historical properties of business cycle. American Economic Review, 82(4), 864-888.

Knafo, S. (2006). The gold standard and the origins of the modern international monetary system. Review of International Political Economy, 13(1), 78-102. http://dx.doi.org/10.1080/09692290500396693

Lassonde, P. (2005). Gold: A Lesson in Monetary History. Mining Engineering, 1, 1-25

Lee, S. P., \& Passell, P. (1979). A New Economic View of American History. New York: W.W. Norton

Marcuzzo, M. C., \& Rosseli, A. (1986). Ricardo and the Gold Standard. Joan Hall. London: Macmillan Academic and Professional Ltd.

Meissner, C. M. (2005). A New World Order: Explaining the International. Journal of International Economics, (66), 385-406. http://dx.doi.org/10.1016/j.jinteco.2004.08.007

Mundell, R. A. (1995). The International Monetary System: The Missing Factor. Journal of Policy Modeling, 17(5), 479-492. http://dx.doi.org/10.1016/0161-8938(95)00053-V

Ruffin, R., \& Gregory, P. (1983). Principles of Economics. Glenview, Illionis: Scott, Foresman and Company.

Ruggiero, M. A. (2002, September 1). The money trilogy: Gold, interest rates and the dollar. Futures (Cedar Falls, 1A).

Sjaastad, L. A. F. S. (1996). The price of gold and the exchange rate. Journal of International Money and Finance, 15(6), 879-897.

Wanniski, J. (1995, February 6). A gold standard coming (Gekko's Guide to Prosperity). National Review.

Yaacob, S. E. (2009). History and Chronology of World Currency Changes. Journal of al-Tamaddun, 4, 107-127.

Yaacob S. E, \& Ahmad, S. (2012), Prospects of Gold Dinar as a Currency: An Analysis Based on Monetary Theory. Jurnal Pengurusan, 36, 161-171.

Yaacob, S. E., Mujani, W. K., Nasohah, Z., Kusrin, Z. M., \& Samuri, M. A. (2012). Gold Dinar as a Supreme 
Currency: Review Based on the History of Islamic Civilisation. Advances in Natural and Applied Sciences, $6(3), 348-356$.

Yaacob, S. E. (2012). Superiority of the Gold Dinar as Currency: Study Based on the History of Islamic Civilization. Islamiyyat, 34, 119-129.

Yaacob, S. E., Ahmad, S., \& Zabaria, W. N. (2011). Currency and the global economic crises: Rationale of the resumption of gold currency. The Journal of Muamalat and Islamic Finance Research, 8(1), 143-159.

Yaacob, S. E. (2012). Study of Implementation Gold Dinar as Currency. World Applied Sciences Journal, 20(7), 1014-1023.

Yaacob, S. E. (2012). The Reality of Gold Dinar Application in Malaysia. Advances in Natural and Applied Sciences, 6(3), 341-347.

\section{Copyrights}

Copyright for this article is retained by the author(s), with first publication rights granted to the journal.

This is an open-access article distributed under the terms and conditions of the Creative Commons Attribution license (http://creativecommons.org/licenses/by/3.0/). 